\title{
Science Learning in Early Childhood Education
}

\author{
I Wayan Sutama ${ }^{\mathrm{a}}$, Ika Al Mumtahanah \\ Faculty of Education, State University of Malang (UM), \\ Malang, Indonesia
}

Corresponding e-mail: wayan.sutamaum@gmail.com, ikaalmumtahanah@gmail.com

\begin{abstract}
Early children experience growth and development in a holistic and integrative way. All aspects of growth and development occur simultaneously, and require proper stimulation and direction. The introduction of science in early childhood is an attempt to provide immediate experience in children, so that children have the opportunity to explore the environment in its own way that is playing. This is because the introduction of science can provide hands-on experience in the form of scientific concepts, the science process, the development of attitudes and utilizing them in solving daily problems. The purpose of this article is to describe how to conduct science learning to early childhood education.
\end{abstract}

Keywords: $\quad$ science, early childhood, science concept, science process, scientific attitude, and problem solving.

\section{INTRODUCTION}

Could the development of science be applied to early childhood? Are early children ready to learn science? What kind of things are relevant for early childhood? Are not young children served with a variety of activities such as singing, folding, cutting, coloring, reading, writing and counting? Various questions like this that often appear in the dynamics of the implementation of early childhood education. Skepticism and stuck in routine activities, as well as some assumptions about the weakness of early childhood positions make services and demands for early childhood education to take place mechanically without meaning. The character of the child is developed through aspects of religious and moral values and social-emotional development. Knowledge development is cognitively charged, the development of language skills centered on the field of language development, the child's motor skills are centered on activities in the field of motor development and artistic expression centered on the field of art development. These areas of development seem to be independent (partial), whereas theoretically conceptual, early childhood learning is integrative thematic [1]

An early child is a person who actively shapes or organizes their own knowledge as they adjust their thinking as they occur when they explore the environment and then grow cognitively against logical thinking. This is in line with Piaget's view who stated that knowledge is created when children interact with the social environment and the natural environment around them [2]. Whatever the child does in daily life is learning. Children actively play and explore their environment, and from these activities children form their knowledge and experience, so that new knowledge is formed and stored in the brain in the schemata form, and then use their knowledge / experience to deal with the situation or new problems they face (accommodation). It is clear through many studies that young children have their own constructions of science phenomena that are in a developmental process of becoming more sophisticated[3]

Therefore, the introduction of science to early childhood is one of the way to facilitate the development of children so that children have direct experience in exploring their environment. This direct experience has an impact on aspects of development, such as the ability to think, speak, physical motor, religious and moral values, and art. In this article will be described how to conduct science learning to early childhood education.

\section{BASIC CONCEPTS OF SCIENCE}

Understanding the concept of science is very important for teachers. This is because it will affect the determination of learning materials and strategies. The child's understanding of science is strongly influenced by the learning experience determined by the teacher's view of science [4]. In another study found, children from three different schools though taught the same subject matter but given by different teachers resulted in a diverse child's understanding. This happens because of the different understanding, way of teaching and different views of science teachers. In summary this concludes that the child's conception of science is strongly influenced by the teacher's view of science.

Science is not just a collection of facts. Of course, facts are an important part of science, but science is much, much more. Science involves: observing what's happening; classifying or organizing information; predicting what will 
happen; testing predictions under controlled conditions to see if they are correct; and drawing conclusions. Science involves trial and errortrying, failing and trying again. Science doesn't provide all the answers. It requires us to be skeptical so that our scientific "conclusions" can be modified or changed altogether as we make new discoveries [5].

Based on the above opinion can be argued that science is not only a collection of facts, but also includes the scientific process. There are several skills in the science process needed in science, ie observing, grouping or compiling information, predicting, testing forecast / prediction and making conclusions. Through the process of science, children will find fact-based science concepts obtained by the child.

In addition, science can also mean a new invention or novelty that can be used to solve problems, called technology. Technology is a real nature of the science application, a logical consequence of science that has the power to do something. Science as a technology used to solve everyday problems. Problem solving starts from simple (for children), to complex and complex things (for adults).

There are some details of the nature of science, among them are as follows. (1) Science is a conceptual building or conceptual scheme that is interconnected as a result of experimentation and observation. (2) Science is the building of knowledge obtained by using the observation method. (3) Science is a system for understanding the universe through data collected through observation or controlled experiments. (4) Science is a problemsolving activity by humans who is motivated by the curiosity of nature around it and the desire to understand, master, and manage it in order to meet needs.

Science has 4 components [6], namely: (1) science as content or product; (2) science as process or methods; Science as attitude; And (4) science as technology. Science as content (material) and product leads to materials or science products learned by the child. In this case children learn facts, laws, principles and theories about science. Science as a process or method, is a way of children to learn the objects of learning. The way children learn about learning objects is through observing, grouping, measuring, using space and time relationships, communicating, predicting, reasoning, making operational definitions, preparing hypotheses, interpreting data, manipulating variables and experimenting. Although this way so much, for the early childhood can be adjusted to the level of child development. Science as an attitude, in carrying out the process of science, children are accustomed and trained to be objective, open, think and be tentative. Children are accustomed not afraid of failure in the science process. Learning is a fun process while challenging children. Finally, science as a technology, children are accustomed to using their knowledge and skills in solving everyday problems. Thus, learning becomes more meaningful and makes children cultured learning (literacy in learning).

Science is also based on an empirical approach with the assumption that this universe can be studied, understood, and explained by not solely dependent on the method of casualty but through a particular process, such as observation, experimentation and rational analysis. In this case also used certain attitudes, such as trying to be as objective as possible, and honest in collecting and evaluating data. Using these scientific processes and attitudes will give rise to new discoveries made into science products. If sciences not only composed of a collection of knowledge or a variety of facts that can be memorized, consisting of the process of actively using, the mind in studying the phenomenon of nature that can not be explained.

Based on several opinions and statements above can be concluded that science is the steps taken in understanding the nature (the process of science) and the resulting knowledge in the form of facts, principles, concepts, and theories (product Science). Both aspects must be supported by the attitude of science (scientific attitude) in the form of beliefs about the value that must be maintained when seeking or developing new knowledge. In addition, knowledge, attitude and the process of science that children learn will lead to the ability to solve problems experienced by children in everyday life based on science.

\section{EARLY CHILDHOOD AND SCIENCE}

Many scholars have investigated how the concept and boundaries of science are viewed from the child's point, among them according to Carson based on his observations of children's behavior when interacting with various objects of science, it can be deduced that science for children is everything that is amazing, something that is found and considered interesting and give knowledge or stimulate it to know and investigate. With these limits, child science can be found all over the place, both at home, in the yard, at school and elsewhere [14]

Very young children can come up with many interesting explanations to make sense of the world around them. When asked about the shape of the earth, for example, some will explain that the earth has to be flat because, if it were round like a ball, people and things would fall off it. Presented with a globe and told that this is the true shape of the earth, these children may adapt their explanation by saying that the earth is hollow and that people live on flat ground inside it [5]

Usually children living in the countryside, catching frogs and tying them with ropes from 
banana stalks and then the frogs are left jumping, and children galloping with their friends watching how toads jump is part of the understanding and behavior of science expressed by them. In contrast, for children living in urban areas, observing the various phenomena of vehicles on the sidewalks that pass by one after another, in their minds there is a speeding, slow pace and some even stop, and die the engine, it is part of the science is also good for Children in the area.

Other concrete examples that are more real, for example are as follows. (1) The child catches a dragonfly, puts it in a jar, observes it and feels it, next comes a sense of pity (compassion), so it grows a better feeling of being released. (2) Children wear jackets in the wet season (cold) and feel them warm during and after wearing them. (3) The child sees and notices a crab and a spider. They compare it, then the question arises in his mind why the two are similar. (4) A child observes adults feeding animals. Slowly he approaches, then next to the adult the child begins to brave the food directly to the animal.

The variety of activities indicates that the child is in a science environment. Children experience literacy in science, because the child's environment is full of facts and processes about science. In addition, the involvement of children in the science process can facilitate the child in developing the attitude of science and belief in God by loving his creation. Utilization of science is also a part of everyday children's lives. Children solve problems by using the principles of science. For example, children swim by using a buoy containing the air.

\section{LEARNING OBJECTIVES OF SCIENCE FOR CHILDREN}

Learning science in early childhood is very important to provide the provision of knowledge to children about nature and all its contents that give meaning to life in the future. The purpose of science learning in children this early age[7], among others, as follows. (1) Helping to grow interest to know and study objects and events in the environment. (2) Helping to understand and be able to apply various concepts of science to explain natural phenomena and solve problems in everyday life. (3) Helping to be able to analyze and cultivate a sense of love to the natural surroundings so as to realize the majesty of God Almighty.

In addition, science play is very important for early childhood because it has several benefits, which can develop the ability of children in the following. (1) Exploration and investigation, namely activities to observe and investigate objects and natural phenomena. (2) Develop basic science process skills, such as observing, measuring, communicating observations and so on. (3) Developing curiosity, pleasure and willingness to engage inquiry or discovery. (4) Understanding the knowledge of various objects both characteristic of structure and function.

\section{SCIENCE IN EARLY CHILDHOOD EDUCATION}

Early childhood is a natural scientist. The child has an interest in something, wonders about something and likes to experiment with something to fulfill his curiosity. Let you show a thing to a child, and give freedom to explore it, then the child will hold, kiss, touch, listen and try it. Often children spontaneously ask things related to the object.

For example, children are invited to play sand and water. Look at the child's reaction, how the child impregnates the sand and water. Children do a variety of activities, start making rain from the sand, making a snack of sand, making tunnels and so forth. The child will be rich with the experience of playing. How does it affect children?

An important part of child development is the qualitative changes in a child's understanding of science concepts in everyday practice. This begins with everyday life experiences and the child's early formation of concepts. By performing a variety of play activities, early childhood began learning to know simple science[3]. Their findings that sand can be made into various forms, children can imagine freely with sand, and children can try and try to treat the sand in accordance with his wishes. This is certainly very useful for cognitive development, language, social (if done together with his friends), and train his motor skills in accordance with the level of growth and development.

\subsection{Science in Early Childhood Life}

Science is an important part of the child's life. Every day children play and interact with their environment. Children have a very wide opportunity to explore their environment through play. With the interaction and exploration of the environment the child gained a rich learning experience.

Learning experiences that can be formed through exploration of the environment include: (1) the formation of wider knowledge; (2) process experience; (3) attitude formation and awareness of values and 4) problem-solving ability. The first experience deals with the formation of scientific concepts, such as the names of animals, the names of plants, the forms of things, the concepts of numbers, patterns, structures, parts, rocks, weather, fire, water, celestial bodies and so forth. The more children interact with their environment, the more the schemata are formed in the minds of children. Therefore, children are given the flexibility in interacting with their environment.

The second experience relates to the experience of the science process. The child is a little magician. Children like to observe the objects that exist around 
it through sensing, such as seeing, kissing, touching, listening and feeling. This sensing experience will lead to new knowledge about what is around it. Children often wonder and ask everything around to others. In addition the child likes to play around (explore) objects that are around him and tell it (communicate) to others. The experience of this science process will greatly expand the child's knowledge of the concepts of science.

The third science experience that children learn about scientific attitudes. Scientific attitudes include high curiosity, questioning, objectivity, openness, and the child realizes that everything that happens around him is tentative. In addition, when doing the process of science, children get a sense of fun, like to try, brave and like berimajinasis and trying to solve the problems it faces.

The fourth science experience is that children are accustomed to solving everyday problems with the knowledge, process and attitude of science that has been experienced or learned. For example, when the child wants to make the ball from the sand and because the sand is dry then the sand ball is not so. Finally the child looks for water and mixes the sand with water so the sand is easily formed into sandballs. In this context, the child may experiment with how much water is needed so that the sand sphere becomes good. Another example, when a child makes ships (plane of paper) and when launched it can not fly away then the child will fix it, for example by widening its wings or enlarge its air bag. In this context, the child has used his science knowledge to solve his daily playing problems. This means that children use science as a technology (science as technology).

\subsection{Science in Early Childhood Education Curriculum}

Science, one of the most important areas in education and its foundation in programs for young children. In Rutherford and Ahlgren opinion[2] explained that science is one of the most important and the basic part in early childhood education program. Children every day interact with the surrounding natural environment. Children are confronted with objects, weather, day and night events every day. Like a scientist, a child will think, form concepts and solve problems faced daily. This will make the child has a consciousness of science and this is very supportive of the development of his intelligence. Therefore adults including early childhood educators should be aware of this and should not hamper it in exploring the environment. Adults should facilitate and maintain the element of child's security and comfort in performing science play activities in their daily life. This is because the child has not understood the elements that can endanger him. Children only understand that they are satisfied and compelled to satisfy their curiosity without thinking about the consequences.

Implementation of science development shows the following. First, judging by the theme explored in early childhood curriculum structure is quite representative. Types of themes in the curriculum 2013 PAUD is myself, my neighborhood, plants, animals, water, fire and air, life in the village and in the city, the universe. All themes presented and explored by early childhood are related to science.

Second, in terms of competence to be achieved include 4 core competencies namely spiritual competence, social competence, knowledge and skills. Each core competence is translated into basic competencies. The achievement of basic competence is obtained through integrative thematic approach and scientific approach [8]. Learning through thematic approach (integrative thematic) emphasizes that children have a learning experience that is intact, and comprehensive and meaningful. This will make the child understand something (learning object) intact (global), and do not understand something partially. Understanding something intact will greatly benefit the child in solving everyday problems. The child will get used to solving the problem in various ways and the corner of the review creatively. While the use of a scientific approach is needed for the child to gain hands-on experience in learning. The child learns by observation (by using all the means of his senses), accustomed to questioning something (as a form of high curiosity), gathering information and conducting experiments (as a way of answering his curiosity), reasoning (by linking an event With other events or events) and skillfully communicate ideas, ideas, feelings and findings [9].

\section{THE ROLE OF EDUCATORS TO INTRODUCE AND DEVELOP THE SCIENCE FOR EARLY CHILDHOOD}

Educators have a very important role in the introduction and development of science. As Bredekamp and Rosengrant[13] points out that there are several types of teacher involvement in learning. (1) Acknowledge. The teacher recognizes the child's efforts and work. By acknowledging, the teacher is accepting and supporting the child to continue his or her task. (2) Model. The teacher provides an example for the child to view. (3) Facilitate. The teacher assists the child in a task by making it easier to complete. Often facilitation is brief, with the hope that the child will be able to continue the task independently. (3) Support. The teacher assists a child, yet provides more time and help in achieving the goal. (4) Scaffold. The teacher provides support while also challenging the child to try something a little more difficult by breaking it down into smaller components. (5) Co-Construct. The teacher and child 
work together toward a goal. For example, the teacher and child complete a large pattern of shapes and colors. The teacher should follow the child's lead and provide encouragement. (6) Demonstrate. The teacher takes an opportunity to present a skill in progressive steps to the child. (7) Direct. The teacher gives specific information to the children.

Meanwhile, the role of educators in learning activities is as planners, implementers and assessors. In accordance with the demands of the implementation of the curriculum in 2013 PAUD, educators are required to be able to plan, implement and assess learning-based scientific approach. Results of research conducted by Sutama, et al[10]. Year 2016 shows the following facts. (1) The ability of kindergarten teachers in making learning planning quite good, with an average score of 67.23. (2) The ability of kindergarten teachers to create a learning situation based on a good science-based approach, with an average of 67,3 . (3) The issues that are most prominent and encountered by most teachers in planning learning based on a scientific approach are (a) Sub-themes; (b) development of activity materials; (c) the supply of resources, media and learning materials; (d) the formulation of the lesson steps; (e) the mastery and implementation of authentic assessments; And (f) making a summary of daily valuation data into weekly and monthly assessments and semester assessments. (4) The problems faced by teachers in creating learning situations based on a scientific approach are: (a) fostering the courage of children to communicate their experiences and interests in apperception activities; (b) create democratic learning, (c) familiarize children with good behavior; (d) manage core activities, especially in applying scientific approaches; (e) utilizing relevant sources and media with a scientific approach; (f) carry out process assessments during the learning activities.

Children's scientific inquiry is guided by the teacher's explicit understanding of the important underlying science concepts of the focus she has chosen). In order for learners to be successful in ECDE science, proper strategies should be applied to give the maximum benefits of scientific skills, activities and ideas[11]. The ability of educators who are not optimal in learning-based scientific approach and the various problems faced need to be studied in depth and followed up. This is because the ability of educators in designing and implementing science learning has an impact on the learning experience, especially on the experience of the science process in children. If the learning experience (the process of science) is not optimal, then the acquisition of knowledge about science, habituation as a scientist attitude and solving problems of children in daily life will also be less than optimal. Therefore, it is necessary to redefine and reconstruct the experience of educators in learning especially related to the introduction and development of science in early childhood.

\section{INTRODUCTION OF SCIENCE THROUGH INFORMATION TECHNOLOGY}

21 th century is marked by the development of information technology is very fast and lead to the digital age. Craft [12] argue that such selfactualization of the child and family in a marketised context, whilst triggered by television, is further expanded by the growth of digital media; a global, if unequal, phenomenon which expands speed of access and modes of transformation into knowledge, with massive implications for education across the world. With access to digital media in and beyond the home from a young age (for example Vandewater et al. (2007) report nearly a third of 5- and 6-year-olds using a computer for 50 minutes on a typical day) and with increasing access to mobile hand-held devices, children and young people are now able to develop a sense of identity, meaning, direction, and even life course progress, through local and global, actual and virtual engagement with others. Use of digital tools (which often facilitate a more developed sense of agency than in a face-to face context) means children and young people are greatly empowered compared with their counterparts 50 years ago.

Learners must be given strong foundation in science through various activities to develop good and sound scientific principles that would help them pursue science-oriented courses like engineering and technology[11].Children from an early age are already dealing and using information technology to gain information and play with digital media. This certainly brings both positive and negative impacts. Parents and early childhood educators should utilize information technology-based media to provide a learning experience and attempt to minimize negative impacts such as the effects of radiation and negative charges such as pornography, sadism and the like.

Utilization of information technology such as television, internet, gadgets in early childhood education can't be avoided anymore. The child is familiar and facilitated by the child's parent and the task of the educator is aligning it for the sake of education. For example, through television children are invited to get to know the life of animals, social life, natural phenomena and so forth. Through a scientific approach, children are invited to observe, question, collect information, give opportunities to reason and communicate to others, according to the stage of child development. Through a variety of interactive games, children can be trained to learn to solve problems in a fun way.

Claxton et al [12]suggests that educators need to be both creative and wise, to motivate and inspire children and young people, attending to the development of thoughtful, responsible and 
sustainable possible futures for themselves and others. This must involve offering children and young people opportunities to develop critical awareness of the consequences of globalised capitalism and extension beyond individualism. This demands imagination of teachers as well of learners. The presence of educators as a child companion in utilizing information technology is needed. Educators need to be creative and wise in motivating and inspiring children so that they can develop their wisdom, responsiveness and possible future sustainability.

The role of teachers has changed and continues to change from being an instructor to becoming a constructor, facilitator, coach, and creator of learning environments. Today teachers are required to be facilitators helping learners to make judgments about the quality and validity of new sources and knowledge, be open-minded and critical independent professionals, be active co-operators, collaborators, and mediators between learners and what they need to know, and providers to scaffold understanding [4]

\section{CONCLUSION}

Introduction and development of science done since early childhood. This is because the child is a natural scientist according to the stage of development. Naturally the child has a high curiosity, observing through sensing, asking questions about what he observes, fulfilling his curiosity by experimenting and manipulating the objects around him and reluctantly sharing his experiences with others.

The introduction of science in early childhood is comprehensively based on the nature of science as a product, process, attitude and technology. As a child product is introduced and attempts to discover concepts, principles and procedures as well as theories about science. As a process, children are trained to perform science skills. As an attitude, children are trained and accustomed to have a scientist attitude. As a technology, children are given the opportunity to learn to solve their daily problems using science.
Parents and educators need to reorient the role in the introduction of science, especially in the digital age. Parents and educators like to be wise and creative in utilizing information technology in the introduction of science for early childhood. Parents and educators act as constructors, facilitators, coaches, and creators of learning environments.

\section{REFERENCES}

[1] Direktorat Pembinaan Pendidikan Anak Usia Dini, Pedoman Perencanaan Pembelajaran Pendidikan Anak Usia Dini, Jakarta: Kemendikbud, 2014.

[2] Seefeldt, Carol dan Nita Barbour, Pendidikan Anak Usia Dini. AlihBahasa: Pius Nasar, New York: Macmillan Colledge Publishing Company, 2008.

[3] Fleer, Marilyn et al, "Studying the landscape of families and children's emotional engagement in science across cultural contexts", International Research in Early Childhood Education, 7 (1), 2016.

[4] Amin, Jayendrakumar N, "Redefining the Role of Teachers in the Digital Era", The International Journal of Indian, 3 (3), No. 6, April - June 2016.

[5] U.S. Department of Education, Helping Your ChildLearn Science, . Washington D.C: U.S. Department of Education, 2005.

[6] Cain, Sandra E dan Jack M. Evans, Sciencing, an Involvement Approach to Elementary Science Methods, $3^{\text {rd }}$ Edition.Colombus: Merrill Publishing Company, 1990.

[7] Mursid, Pengembangan Pembelajaran Paud, Bandung: Remaja Rosdakarya, 2015.

[8] Permendikbud No. 146 Tahun 2014 Tentang Kurikulum 2013 Pendidikan Anak Usia Dini, Jakarta: Kementerian Pendidikan dan Kebudayaan, 2014.

[9] Sutama, I Wayan, ImplementasiKurikulumPaud 2013 dalam MewujudkanAnak Indonesia Harapan. Makalah disampaikan dalam Seminar Nasional Implementasi Kebijakan Ujian Nasional, Dualisme Kurikulum dan Seleksi Masuk Perguruan Tinggi, yang diselenggarakan oleh Fakultas Ilmu Pendidikan tanggal 15-16 Mei 2015.

[10] Sutama, I Wayan, WuriAstuti, Sandy Tegariani, Kemampuan Guru Dalam Melaksanakan Pembelajaran Berbasis Pendekatan Sainstifik Di TK Se KecamatanTumpang, Malang, Malang: UniversitasNegeri Malang, 2016.

[11] Andiema, Nelly C, "Effect of Child Centred Methods on Teaching and Learning of Science Activities in Pre-Schools in Kenya", Journal of Education and Practice, 7 (27), 2016.

[12] Craft, Anna, "Childhood In A Digital Age: Creative Challenges for Educational Futures", London Review of Education, 10 (2), July 2012, 173-190.

[13] Mark K. McQuillan, Early Education, A Guide to Early Childhood Program Development. State of Connecticut, state Board of Education, 2007.

[14] Nugraha, Ali, Pengembangan Sains Pada Anak Usia Dini, Jakarta: Dikti Depdiknas, 2005. 